\title{
Peningkatan Pengetahuan Masyarakat Tentang Pencegahan Covid-19 Melalui Program Kemitraan Masyarakat
}

\author{
Diana Vanda Doda ${ }^{1,2^{*}}$, Youla Annatje Assa ${ }^{1}$, Martha Marie Kaseke ${ }^{1}$ \\ ${ }^{1}$ Fakultas Kedokteran, Universitas Sam Ratulangi \\ ${ }^{2}$ Fakultas Kesehatan Masyarakat, Universitas Sam Ratulangi \\ *Penulis Korespondensi. Email: vandadoda@unsrat.ac.id
}

\begin{abstract}
ABSTRAK
Pandemi Corona Virus (Covid-19) masih tetap terus menunjukkan angka kesakitan dan kematian yang tinggi di seluruh dunia. Di Indonesia penyebarannya semakin tinggi. Penularan yang tinggi ini bisa disebabkan oleh perilaku masyarakat yang kurang baik terhadap program pencegahan yang sudah diinformasikan dan di instruksikan oleh Pemerintah, oleh sebab itu perlu untuk dilakukan program untuk meningkatkan pengetahuan dan merubah sikap dan meningkatkan tindakan agar bisa meminimalisir penyebaran Covid-19. Program Kemitraan Masyarakat (PKM) ini dilakukan di salah satu kelurahan di kota Manado bertujuan untuk memberikan dan peningkatkan pengetahuan masyarakat tentang pencegahan Covid-19, melalui penyuluhan kesehatan, sosialisasi dan diskusi. Kegiatan ini juga membantu masyarakat yang terdampak oleh pandemi Covid 19 dengan membagikan kebutuhan pokok. Kegiatan PKM ini dihadiri oleh 33 peserta. Kegiatan ini di ikuti dengan pengambilan data tentang perilaku masyarakat terhadap program pencegahan Covid-19, dan 23 peserta mengisi kuesioner yang dibagikan. Hasil analisa data tersebut menunjukan bahwa $91 \%$ peserta mempunyai pengetahuan yang baik tapi hanya $61 \%$ mempunyai sikap yang baik dan 52\% melakukan tindakan pencegahan Covid-19 yang baik. Pengetahuan Masyarakat tentang pencegahan Covid-19 di kelurahan mitra sudah baik namun sikap dan tindakan masih perlu ditingkatkan.
\end{abstract}

Kata Kunci: Covid-19, Corona Virus, Pandemi

\begin{abstract}
The Corona Virus (Covid-19) pandemic continues to show high morbidity and mortality rates throughout the world. In Indonesia, the spread of covid-19 is getting higher. The high transmission can be caused by poor community behavior towards prevention programs that have been informed and instructed by the Government, therefore it is necessary to carry out programs to increase knowledge and change attitudes and increase actions towards preventing Covid-19 to minimize the spread of Covid. 19. The Community Partnership Program (PKM) is carried out in one of the sub-districts in the city of Manado to provide and increase public knowledge about the prevention of Covid-19 through health education, socialization, and discussions with the community. This activity also helps people affected by the Covid 19 pandemic by sharing basic needs. The PKM activity was attended by 33 participants. This activity was followed by data collection about people's behavior towards the Covid 19 prevention program, and 23 participants filled out questionnaires that were distributed. The results of the data analysis show that $91 \%$ of participants have good knowledge but only $61 \%$ have a good attitude and 52\% take good preventive measures for Covid 19. Public knowledge of the prevention of Covid-19 in partners village was good however attitudes and actions still need to be improved.
\end{abstract}

Keywords: Covid-19, Corona Virus, Pandemic 


\section{PENDAHULUAN \\ Analisis Situasi}

Penyebaran Corona Virus (CoV) diseluruh dunia sehingga terjadi pandemi Covid-19 merupakan masalah dunia yang serius. Angka Kematian dan Kesakitan terus meningkat sampai dengan saat ini. Pertama kali kasus penyakit Corona Virus berupa pneumonia dilaporkan di Wuhan, Tiongkok pada bulan Desember 2019. Masa inkubasi 1-12, 5 hari atau 5-6 hari.

Di Indonesia penyebaran virus ini dilaporkan pertama kali pada bulan Maret 2020. Laporan dari Satuan Tugas Covid-19 Propinsi Sulut, dalam 2 hari, pada tgl 28 Oktober dan 29 Oktober, terdapat peningkatan kasus dari 44 kasus menjadi 109 kasus baru positve Covid-19 di Sulawesi Utara. Angka kematian mencapai 3,74\%. Laporan Pemerintah kota Manado sampai dengan akhir Oktober, di kecamatan Malalayang terdapat 284 orang terkonfirmasi Covid-19 dan 16 penderita meninggal, sedangkan di Kelurahan Batukota terdapat 14 orang positif Covid-19 (https://covid19.manadokota.go.id/).

Update terakhir yang dipublish WHO, Indonesia melaporkan sebanyak 1.051 .795 kasus yang terkonfirmasi Covid-19, 29.518 Kematian, namun 852.260 pasien yang sembuh (WHO, 2021).

Obat dan vaksin belum ditemukan, namun langkah-langkah pencegahan sudah dilakukan. Virus ini bisa menyebabkan sakit ringan atau tanpa sakit sampai dengan sakit berat bahkan kematian. Cara penularan Virus Corona ini menurut Centers for Diseases Control and Prevention (CDC, 2020):

1. Menghirup droplet atau percikan ludah oleh penderita Covid 19 pada saat penderita bersin atau batuk;

2. Menyentuh benda yang terkena droplet penderita Covid-19, dan tangan kita menyentuh mulut, hidung dan mata sebelum sempat mencuci tangan.

3 . Kontak dekat ( 6 feet) dengan penderita yang terinfeksi covid-19.

Cara penularan virus ini harus diketahui masyarakat agar dapat mengimplementasikan cara pencegahannya baik untuk diri sendiri maupun untuk orang lain. Cara untuk pencegahan buat diri sendiri dan orang lain yaitu (CDC, 2020):
- Pencegahan virus ini, sebaiknya menghindari terekpose dengan virus

- Gunakan masker menutupi hidung dan mulut saat berada dengan orang lain atau ditempat publik, seperti pasar, sekolah, mall dan lainlain.

- Sebanyak mungkin tinggal dirumah dan jauhi kontak dengan orang lain.

- Sesering mungkin membersihkan dengan desinfektant permukaan yang sering tersentuh.

- Sesering mungkin mencuci tangan dengan sabun dan air mengalir atau menggunakan handsanitiser alkohol yang mengandung $60 \%$ alkohol.

- menerapkan sosial distancing. Misalnya pergi berbelanja sebaiknya menggunakan masker dan menjaga jarak dengan orang lain, namun disarankan apabila dilakukan secara online akan lebih aman.

- Bila bepergian sebaiknya menghindari angkutan umum.

- Apabila sakit, harus tinggal dirumah, kecuali membutuhkan pelayanan medis. Tidak ada obat khusus buat Covid-19, pengobatan hanya berdasarkan symptom yang ada.

- Orang tua atau lansia dan orang yang mempunyai comorbid merupakan risiko tinggi untuk mendapatkan sakit yang parah.

\section{Tujuan dan Manfaat Kegiatan}

Tujuan dan Manfaat yang didapatkan dari kegiatan ini adalah:

1. Meningkatkan pengetahuan tentang Covid dan pencegahan penularannya.

2. Mendapatkan data tentang pengetahuan masyarakat yang bisa digunakan sebagai data awal untuk sebuah penelitian.

3. Memberikan kontribusi pada Instansi yang terkait tentang peningkatan Program Kesehatan khususnya Covid 19.

4. Masyarakat mendapatkan bantuan APD (Masker) dan handsanitiser untuk menunjang implementasi program pencegahan Covid-19 di masyarakat.

5. Masyarakat yang terdampak Covid bisa mendapatkan bantuan berupa bahan pokok (Beras). 


\section{METODE PELAKSANAAN Sasaran kegiatan}

Sasaran dari kegiatan Program Kemitraan Masyarakat ini adalah masyarakat umum dan masyarakat yang terdampak pandemi Covid-19.

\section{Lokasi kegiatan}

Kegiatan dilakukan di gedung gereja GMIM Yerusalem Batukota. Kegiatan ini merupakan kerjasama dengan mitra Kelurahan Batukota linkungan 1 dan Komisi Pria Kaum Bapa Jemaat Yerusalem Batukota.

\section{Metode yang digunakan :}

Kegiatan pengabdian pada masyarakat ini dilakukan dengan beberapa tahapan sebagai berikut :

\section{Persiapan}

Dalam rangka Program Kemitraan Masyarakat khususnya kelompok yg terdampak Covid-19 maupun masyarakat gereja, maka akan dilakukan pendekatan dan memberikan informasi untuk menyiapkan diri dalam pelaksanaan penyuluhan dengan cara mendapatkan persetujuan dari kelurahan dan komisi kesehatan gereja untuk menyebarkan informasi tentang kegiatan PKM ini.

2. Komunikasi Tim Pelaksana kegiatan dengan ketua kelompok dilakukan secara intensif antara lain menyangkut teknis pelaksanaan yaitu tempat pelaksanaan yang sesuai, waktu yang tepat dan lainlain.

3. Pelaksanaan Pengabdian Kepada masyarakat

a. Kegiatan penyuluhan dilakukan oleh tim. Pelaksanaan kegiatan dilakukan dengan metode ceramah/penyuluhan, diskusi/tanya jawab Metode ceramah/penyuluhan dilakukan untuk memberikan pengetahuan dasar mengenai pencegahan Covid 19. Materi disampaikan dalam bentuk power point. Metode diskusi/tanya jawab dilakukan untuk memberi kesempatan kepada anggota masyarakat untuk bertanya maupun bertukar informasi dengan pembicara sehingga bisa memperoleh pemahaman yang lebih baik mengenai topik yang dibicarakan.

b. Setelah dilakukan Penyuluhan dilakukan pengambilan data dengan kuesioner untuk mengetahui pengetahuan, sikap dan tindakan peserta terhadap program pencegahan Covid 19.

c. Pemeriksaan tekanan darah pada peserta lansia oleh tim kesehatan Gereja Yerusalem Batukota.

4. Diskusi Tim Pelaksana dan Pelaporan

Setelah pelaksanaan kegiatan pengabdian kepada masyarakat, tim pelaksana melakukan pertemuan untuk mengevaluasi dan melaporkan pelaksanaan PKM. Pelaporan di tujukan ke Universitas Sam Ratulangi, Lurah Batukota dan Pimpinan Gereja Yerusalem Batukota. Tim Pelaksana mengharapkan tujuan pelaksanaan PKM dapat tercapai dan dapat dilakukan oleh mitra secara kontinue.

\section{HASIL DAN PEMBAHASAN}

Adapun hasil kegiatan yang diperoleh adalah sebagai berikut :

1. Kegiatan PKM dihadiri oleh 33 peserta dengan 1 narasumber dan 1 moderator.

2. Materi yang diberikan berjudul: Meningkatan Pengetahuan tentang Pencegahan Covid 19. Penyuluhan ini dilakukan presentasi dalam bentuk power point dan diskusi tanya jawab antara narasuber dan peserta.

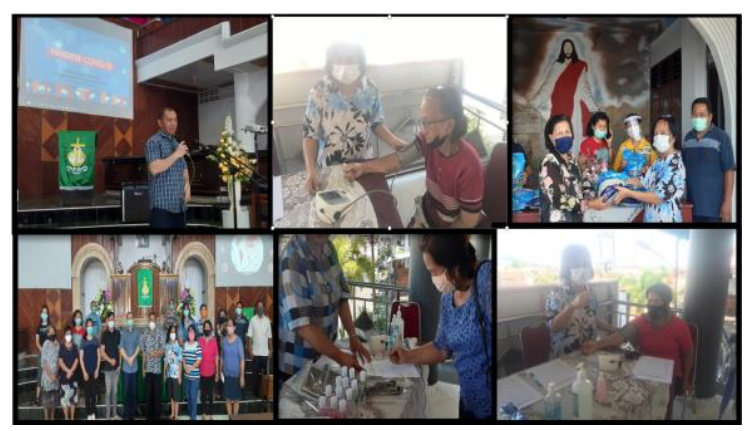

Gambar 1. Kegiatan PKM Batukota

3. Pemberian bantuan berupa hansanitiser dan masker kepada 33 peserta dan bantuan bahan pokok berupa Beras $5 \mathrm{~kg}$.

4. Setelah dilakukan penyuluhan dilakukan pengambilan data melalui kuesioner terdiri dari informasi peserta, serta kuesioner perilaku responden terkait pengetahuan, sikap dan tindakan terhadap pencegahan Covid-19. Kuesioner dibagikan kepada 33 peserta, namun hanya sebanyak 23 peserta yang menyelesaikan pengisian kuesioner dan mengembalikan kepada tim PKM.

Hasil dari data yang dikumpul ditemukan median umur responden adalah 24 
tahun, dengan umur minimal 17 tahun dan maksimal 56 tahun, persentase jenis kelamin hampir sama yaitu $52 \%$ lelaki dan $48 \%$ perempuan. Responden mempunyai tingkat pendidikan SMA $44 \%$ dan diatas SMA sebanyak $56 \%$.

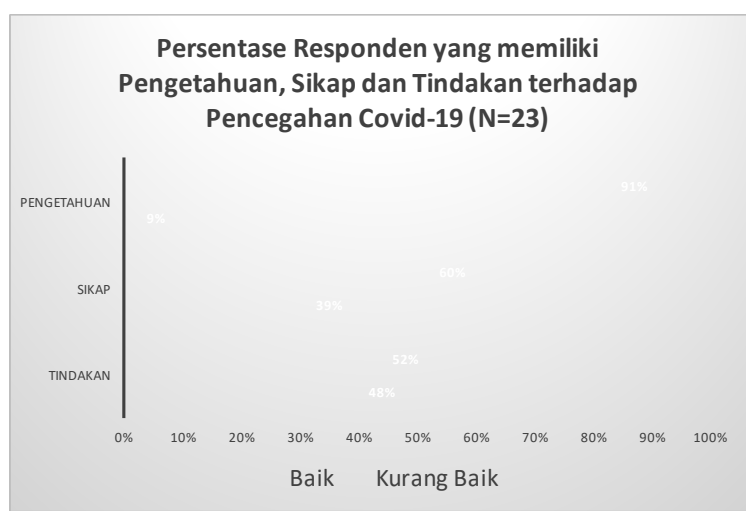

Gambar 2. Deskripsi Pengetahuan, Sikap dan Tindakan Responden terhadap pencegahan Covid-19

Peserta yang mempunyai pengetahuan yang baik (91\%), namun masih sedikit peserta yang mempunyai sikap positif $(60 \%)$ dan tindakan yang baik terhadap pencegahan Covid19 (52\%). Penelitian sebelumnya di Indonesia tentang pengetahuan, sikap dan perilaku terhadap salah satu pencegahan Covid-19 dengan 1,102 responden menemukan hasil yang hampir sama, dimana majoritas responden $99 \%$ memiliki pengetahuan yang baik namun hanya $56 \%$ melaporkan sikap yang positif, namun mereka melaporkan mempunyai perilaku yang baik 93\% (Yanti, 2020). Sejalan dengan penelitian di Saudi Arabia dengan tiga ribuan responden menemukan bahwa majoritas sudah mempunyai pengetahuan yang baik tentang Covid, dan rata2 mempunyai score yang baik untuk sikap dan praktek pencegahan Covid-19 (Al-Hanawi, 2020). Berbeda dengan penelitian di Bangladesh, menunjukkan kurang dari 50\% partisipan mempunyai pengetahuan yang baik (48.3\%), yang mempunyai sikap positif $62.3 \%$ dan hanya $55.2 \%$ sering melakukan tindakan pencegahan Covid-19 (Ferdous, 2020).

Hasil penelitian dalam kegiatan PKM menggambarkan bahwa tidak selamanya pengetahuan yang baik, di ikuti oleh sikap dan/ atau tindakan yang baik juga, meskipun penelitian-penelitian sebelumnya tersebut menyatakan bahwa pengetahuan penting untuk merubah sikap dan tindakan terhadap pencegahan Covid-19. Menurut teori Bloom perilaku manusia terdiri dari kognitif (pengetahuan), afektif (sikap) dan Psikomotor (tindakan). Pengetahuan merupakan domain yang sangat penting dalam pembentukan tindakan seseorang, sehingga dengan adanya pengetahuan diharapkan seseorang dapat merubah sikap dan tindakan sesuai dengan pengetahuan yang ia miliki (Notoatmojo, 2007). Perubahan tindakan seseorang kearah yang lebih baik memerlukan juga sikap yang positif dan faktor-faktor pendukung lainnya (Notoatmojo, 2012), oleh sebab itu perlu adanya faktor pendukung lain di samping Pengetahuan yang baik, untuk merubah sikap dan tindakan masyarakat terhadap pencegahan Covid-19, misalnya ketersediaan alat pelindung diri (APD) dan lain-lain.

\section{KESIMPULAN DAN SARAN}

Kegiatan Program Kemitraan Masyarakat ini adalah masyarakat umum dan masyarakat yang terdampak pandemi Covid-19.Kegiatan Program Kemitraan Masyarakat dihadiri oleh 33 peserta dengan materi penyuluhan yang berjudul: Meningkatkan Pengetahuan tentang Pencegahan Covid-19. Kegiatan PKM ini juga diikuti dengan pengambilan data tentang pengetahuan, sikap dan tindakan terhadap pencegahan Covid-19. Hasil penelitian menunjukkan bahwa pengetahuan masyarakat tentang pencegahan Covid-19 di kelurahan mitra sudah baik namun sikap dan tindakan masih perlu ditingkatkan. Perlu adanya faktorfaktor pendukung untuk meningkatkan sikap positif dan tindakan yang baik.

\section{UCAPAN TERIMAKASIH}

Tim PKM menyampaikan terima kasih kepada Lembaga Penelitian dan Pengabdian Masyarakat Universitas Sam Ratulangi (LPPM- Unsrat) yang telah mendanai kegiatan Program Kemitraan Masyarakat tahun pendanaan 2020. Terima kasih juga disampaikan kepada mitra PKM yaitu kelompok masyarakat Batukota Lingkungan I dan Jemaat GMIM Yerusalem Batukota, Kelurahan Batukota, Malalayang Manado.

\section{DAFTAR PUSTAKA}

Al-Hanawi, M.K., Angawi, K., Alshareef, N., et al.,2020. Knowledge, attitude and practice toward COVID-19 among the public in the Kingdom of Saudi Arabia: a cross-sectional study. Frontiers in Public Health, 8. 
Ferdous, M.Z., Islam, M.S., Sikder, M.T., et al., 2020. Knowledge, attitude, and practice regarding COVID-19 outbreak in Bangladesh: An online-based crosssectional study. PloS one, 15(10), p.e0239254.

CDC, 2020. What you should know about COVID-19 to protect yourself and others. https://www.cdc.gov/coronavirus/2019ncov/downloads/2019-ncov-factsheet.pdf

Kementerian Kesehatan Republik Indonesia, 2020. Pedoman Pencegahan danPengendalian Corona Virus Diaseases (COVID-19).

Liputan 6 (2020), Lonjakan Kasus Baru Positif Covid-19 di Sulut Mengkhawatirkan. https://www.liputan6.com/regional/read/ 4395576/lonjakan-kasus-baru-positifcovid-19-di-sulut-mengkhawatirkan

Poernomo, 2020. KOPIDPEDIA -Bunga Rampai Artikel COVID-19. Pusat Penerbitan Universitas (P2U) Unisba. Bandung

Notoadmodjo, S., 2007. Promosi Kesehatan dan Ilmu Perilaku. Jakarta: Rineka Cipta

Notoatmodjo, S., 2012. Promosi kesehatan dan perilaku kesehatan. Jakarta: rineka cipta, pp.45-62.

Susilowati Dwi, 2016. Promosi Kesehatan http://bppsdmk.kemkes.go.id/pusdiksdmk /wp-content/uploads/2017/08/PromkesKomprehensif.pdf

WHO, 2019. Coronavirus diseases (Covid-19). https://www.who.int/emergencies/disease s/novel-coronavirus-2019

WHO, 2021. Update on coronavirus disease in Indonesia.

https://www.who.int/indonesia/news/nov el-coronavirus

Yanti, B., Wahyudi, E., Wahiduddin, W., et al., 2020. Community knowledge, attitudes, and behavior towards social distancing policy as prevention transmission of COVID-19 in Indonesia. Jurnal Administrasi Kesehatan Indonesia, 8(2), pp.4-14. 